Article

\title{
Corrosion Resistance of Heat-Treated Ni-W Alloy Coatings
}

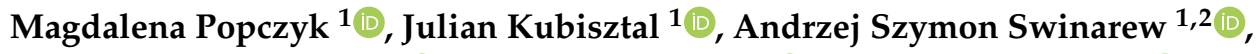 \\ Zbigniew Waśkiewicz 2,3 ${ }^{\mathbb{D}}$, Arkadiusz Stanula ${ }^{2}$ (D) and Beat Knechtle ${ }^{4, *}$ (D) \\ 1 Faculty of Science and Technology, University of Silesia in Katowice, 41-500 Chorzów, Poland; \\ magdalena.popczyk@us.edu.pl (M.P.); julian.kubisztal@us.edu.pl (J.K.); andrzej.swinarew@us.edu.pl (A.S.S.) \\ 2 Institute of Sport Science, The Jerzy Kukuczka Academy of Physical Education, 40-065 Katowice, Poland; \\ z.waskiewicz@awf.katowice.pl (Z.W.); a.stanula@awf.katowice.pl (A.S.) \\ 3 Department of Sports Medicine and Medical Rehabilitation, Sechenov University, 119991 Moscow, Russia \\ 4 Institute of Primary Care, University of Zurich, 8091 Zurich, Switzerland \\ * Correspondence: beat.knechtle@hispeed.ch
}

Received: 30 January 2020; Accepted: 3 March 2020; Published: 6 March 2020

check for updates

\begin{abstract}
The paper presents research on evaluation of corrosion resistance of $\mathrm{Ni}-\mathrm{W}$ alloy coatings subjected to heat treatment. The corrosion resistance was tested in $5 \% \mathrm{NaCl}$ solution by the use of potentiodynamic polarization technique and electrochemical impedance spectroscopy. Characteristics of the Ni-W coatings after heat treatment were carried out using scanning electron microscopy, scanning Kelvin probe technique and X-ray diffraction. Suggested reasons for the improvement of properties of the heat treated $\mathrm{Ni}-\mathrm{W}$ coating, obtained at the lowest current density value $\left(125 \mathrm{~mA} \cdot \mathrm{cm}^{-2}\right)$, are the highest tungsten content (c.a. 25 at.\%) as well as the smallest and the most homogeneous electrochemically active surface area.
\end{abstract}

Keywords: Ni-W alloy coating; heat treatment; corrosion resistance

\section{Introduction}

The electroplating technique is increasingly used to obtain new materials with specific functional properties. This is due to the fact that by controlling the deposition parameters, i.e. voltage, current, bath composition, temperature, it is possible to influence the structure of the obtained material, and hence its properties. The advantage of this method is the possibility of simultaneously co-depositing several metals as well as incorporation powders of metals, non-metals or chemical compounds into the coating [1-44]. Thus, the electroplating technique allows obtaining alloy and composite coatings (amorphous or crystalline) with a specific chemical and phase composition, as well as modelled surface morphology. Many metals are currently used as electrode materials in various electrochemical processes. Among them are the metals from the group of irons, especially nickel, which is characterized by good corrosion resistance and high catalytic activity in the process of hydrogen evolution. In order to improve the utilization of nickel coatings, various methods of their modifications could be applied, such as the use of alloys instead of pure elements. The interest in electrodeposited nickel - tungsten alloys is due to their specific magnetic, electrical, mechanical, thermal and corrosion properties [19-39,44]. These alloy coatings are widely used in the elements of machines operating under high mechanical load, at high temperatures, as well as in aggressive environments. Ni-W coatings are also used as electrode materials for hydrogen evolution reaction (HER) $[2,19,40]$. It should be noted that nickel - tungsten alloys can only be obtained from aqueous solutions through an induced code position, that is, tungsten is code posited with nickel. Sulphate, sulfamine and citrate baths with the addition of sodium tungstate are usually used $[19-39,44]$. 
Generally, heat treatment of electrolytic coatings should increase their corrosion resistance what was confirmed in earlier studies e.q. in $[10,13,15,17,41]$. The formation of new phases and the reduction of the active surface after heat treatment are the main reasons for improving the corrosion resistance of these materials. Thus, we expect that heat treatment of investigated Ni-W alloy coatings can also significantly slow down corrosion processes occurring on its surface.

According to our knowledge there is lack of information about corrosion resistance of Ni-W coatings subjected to heat treatment in the air. Thus, the aim of this work is to study corrosion properties of heat-treated $\mathrm{Ni}-\mathrm{W}$ coatings in $5 \% \mathrm{NaCl}$ solution especially with respect to surface morphology, chemical and phase composition. The Ni-W coatings were deposited under galvanostatic conditions at the following cathodic current densities: 125, 150, 175 and $200 \mathrm{~mA} \cdot \mathrm{cm}^{-2}$. The heat treatment of all coatings was carried out at a temperature of $1173 \mathrm{~K}$. Therefore, the coatings discussed in the article were marked as follows: C125/1173, C150/1173, C175/1173 and C200/1173.

\section{Materials and Methods}

The Ni-W alloy coatings were obtained by electroplating from the electrolyte of the following composition (concentrations in $\mathrm{g} \cdot \mathrm{dm}^{-3}$ ): $\mathrm{NiSO}_{4} \cdot 7 \mathrm{H}_{2} \mathrm{O}-13, \mathrm{Na}_{2} \mathrm{WO}_{4} \cdot 2 \mathrm{H}_{2} \mathrm{O}-68, \mathrm{C}_{6} \mathrm{H}_{5} \mathrm{O}_{7} \mathrm{Na}_{3} \cdot 2 \mathrm{H}_{2} \mathrm{O}-200$ and $\mathrm{NH}_{4} \mathrm{Cl}-50$. For preparation of the bath ultrapure water (Millipore, $18.2 \mathrm{M} \Omega \mathrm{cm}$ ) and 'analytical grade' reagents (Avantor Performance Materials Poland S.A.) were used. The coatings were deposited galvanostatically at the current densities $125,150,175$ and $200 \mathrm{~mA} \cdot \mathrm{cm}^{-2}$ and temperature of $343 \mathrm{~K}$. The coatings were deposited on the steel (S235) plate of $1.0 \mathrm{~cm}^{2}$ geometric surface area. A platinum mesh served as an auxiliary electrode. The chemical composition of the as-deposited Ni-W alloy coatings is presented in Table 1.

Table 1. Chemical composition of the as-deposited Ni-W alloy coatings determined by energy dispersive spectroscopy, in dependence on deposition current density.

\begin{tabular}{ccc}
\hline Type of As-Deposited Coatings & At. $\%$ Ni & At. $\%$ W \\
\hline $\mathrm{Ni}-\mathrm{W}\left(j_{\text {dep }}=125 \mathrm{~mA} \cdot \mathrm{cm}^{-2}\right)$ & $75.4 \pm 0.4 \%$ & $24.6 \pm 0.4 \%$ \\
$\mathrm{Ni}-\mathrm{W}\left(j_{\text {dep }}=150 \mathrm{~mA} \cdot \mathrm{cm}^{-2}\right)$ & $77.3 \pm 0.2 \%$ & $22.7 \pm 0.2 \%$ \\
$\mathrm{Ni}-\mathrm{W}\left(j_{\text {dep }}=175 \mathrm{~mA} \cdot \mathrm{cm}^{-2}\right)$ & $78.5 \pm 0.7 \%$ & $21.5 \pm 0.7 \%$ \\
$\mathrm{Ni}-\mathrm{W}\left(j_{\text {dep }}=200 \mathrm{~mA} \cdot \mathrm{cm}^{-2}\right)$ & $80.2 \pm 0.1 \%$ & $19.8 \pm 0.1 \%$ \\
\hline
\end{tabular}

Heat treatment of Ni-W alloy coatings was carried out in a muffle stove of the type FCF 2.5 SHMgO (Czylok Company, Jastrzębie-Zdrój, Poland) at $1173 \mathrm{~K}$ for $1 \mathrm{~h}$ in the air.

The surface morphology and chemical composition of the heat-treated coatings was studied using a scanning electron microscope (SEM, JEOL JSM-6480, JEOL Ltd., Tokyo, Japan) equipped with an energy dispersive spectroscopy (EDS) detector (JEOL Ltd., Tokyo, Japan). The phase composition was determined by means of X-ray diffraction method using Philips X'Pert PW 3040/60 X-ray diffractometer $(\mathrm{U}=40 \mathrm{kV}, \mathrm{I}=30 \mathrm{~mA}$, Panalytical, Almelo, Netherlands) with copper radiation $(\lambda(\mathrm{Cu} \mathrm{K} \alpha)=1.54178 \AA)$. The data collection was over the 2-theta range of $20^{\circ}$ to $120^{\circ}$ in steps of $0.02^{\circ}$.

Corrosion resistance of the heat-treated coatings was determined, using potentiodynamic polarization technique and electrochemical impedance spectroscopy (EIS). These measurements were carried out in a $5 \mathrm{wt} . \% \mathrm{NaCl}$ solution, using three-electrode cell and an AUTOLAB ${ }^{\circledR}$ electrochemical system (PGSTAT30, Metrohm Autolab B.V., Utrecht, Netherlands). The auxiliary electrode was a platinum mesh and the reference electrode was a saturated calomel electrode (SCE). Potentiodynamic curves were recorded in the potential range $\pm 100 \mathrm{mV}$ versus open circuit potential with rate $v=1 \mathrm{mV} \cdot \mathrm{s}^{-1}$.

The electrochemical impedance spectroscopy was performed at the corrosion potential. In these measurements, the amplitude of the ac signal was $10 \mathrm{mV}$. A frequency range from $10 \mathrm{kHz}$ to $0.1 \mathrm{~Hz}$ was covered with 10 points per decade. All electrochemical investigations were made at $298 \mathrm{~K}$. 
Contact potential difference $(C P D)$ maps and surface topography maps of the heat-treated coatings were recorded by means of Scanning Kelvin Probe (SKP) technique using PAR Model 370 Scanning Electrochemical Workstation (Princeton Applied Research, Oak Ridge, USA) equipped with a tungsten Kelvin probe (KP). The scanning area was $4000 \times 4000 \mu \mathrm{m}^{2}$ and the distance between the probe and the sample was ca. $100 \mu \mathrm{m}$.

\section{Results and Discussion}

The heat-treated Ni-W coatings are characterized by grey, smooth and uniform surface. The surface morphology of the coatings differs, which means it depends on the deposition current density (Figure 1). The surface of C125/1173 coating shows small, separately located globules changing into larger ones with increasing of deposition current density. Coatings obtained at low current density values have a poorly developed surface. It can be explained by that low current densities favor the slow discharge of ions at electrodes, and therefore the growth rate of the resulting grains exceeds the speed of forming of new ones. As the current density increases, the rate of formation of new grains also increases what result in more developed surface. The increase in the density of the deposition current causes intense hydrogen evolution, which in turn can cause the formation of porous coatings.
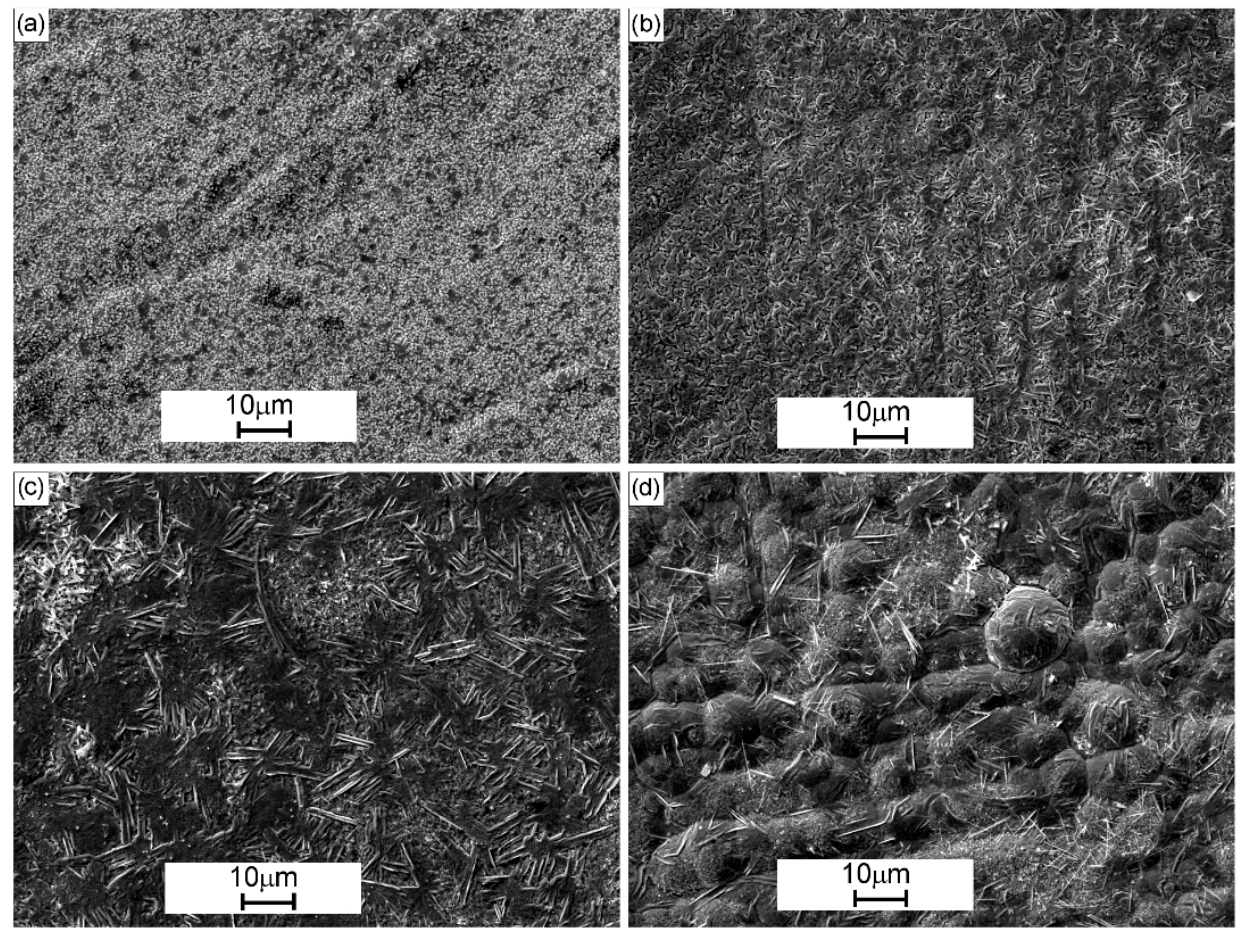

Figure 1. Surface morphology of Ni-W coatings after heat treatment in the air, in dependence on deposition current density: (a) C125/1173, (b) C150/1173, (c) C175/1173 and (d) C200/1173.

The phase composition of the as-deposited Ni-W alloy coatings is independent of applied current conditions. All X-ray diffraction patterns show the presence of reflexes coming from solid solution of $\mathrm{W}$ in Ni. An example of X-ray diffraction pattern obtained for Ni-W coating deposited at current density of $175 \mathrm{~mA} \cdot \mathrm{cm}^{-2}$ is shown in the Figure 2a. The phase composition of the Ni-W alloy coatings after heat treatment is also independent of applied current conditions. During the heat treatment in the air the solid solution of tungsten in nickel breaks down and chemical reaction with oxygen proceeds leading to a formation of new phases. X-ray diffraction patterns shown in Figure $2 b-e$ indicate that the $C 125 / 1173, C 150 / 1173, C 175 / 1173$ and $C 200 / 1173$ coatings consist of three phases, i.e., $\mathrm{Ni}_{4} \mathrm{~W}, \mathrm{WO}_{2}$ and $\mathrm{WO}_{3}$. 

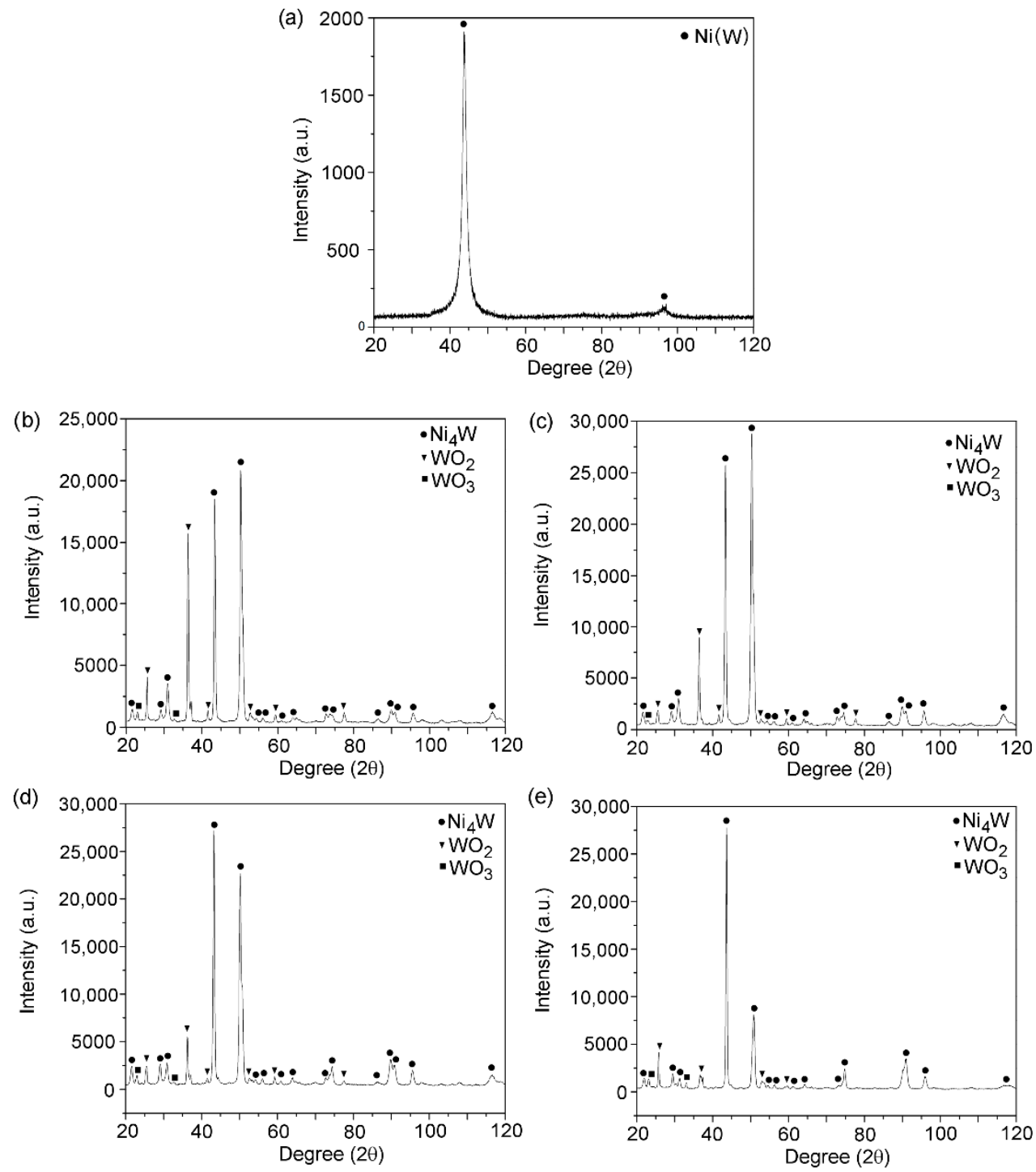

Figure 2. X-ray diffraction patterns for the as-deposited (a) C175/- and after heat treatment (b) C125/1173, (c) C150/1173, (d) C175/1173, (e) C200/1173 Ni-W coatings.

Values of the corrosion parameters i.e. corrosion potential $E_{\text {corr }}$ and corrosion current density $j_{\text {corr }}$ were determined from measured dependencies $j=f(E)$. It was found that the value of the corrosion potential for the C125/1173 coating is the highest compared to the $E_{\text {corr }}$ obtained for the coatings deposited at larger current densities i.e. C150/1173, C175/1173 and C200/1173 (Figure 3, Table 2). It was also noted that, for the $\mathrm{C} 125 / 1173$ coating, the value of corrosion current density is lower compared to the other coatings (Table 2). This suggests that the C125/1173 coating, is more corrosion resistant in $5 \mathrm{wt} . \% \mathrm{NaCl}$ solution than the other investigated coatings. It should be added that all heat-treated $\mathrm{Ni}-\mathrm{W}$ coatings are characterized by the definitely higher corrosion resistance compared to the substrate (corrosion potential of S235 steel is $-739 \mathrm{mV}$ ) [4].

The results of the EIS investigations presented in the form of Nyquist plots $\left(-Z^{\prime \prime}=f\left(Z^{\prime}\right)\right)$ were shown in Figure 4. For all investigated coatings one semicircle in the whole range of frequencies is observed. It has been found that this behavior of the heat-treated Ni-W coatings could be described by one-CPE electrode model (Figure 5). This is typical model for rough or porous materials. Such equivalent circuit is characteristic for materials composed of cylindrical pores of radius $r$ and length $l$. As was shown in a paper [45] for short and wide pores $l^{2} / r$ is very small and only one semicircle on the complex plane plot (Nyquist plot) was observed. The one-CPE model consists of 
the solution resistance $R_{\mathrm{S}}$ in series with a parallel connection of the CPE element $\left(Z_{\mathrm{CPE}}=1 /[\mathrm{j} \omega)^{\phi} T\right]$ where $T$ is the capacitive parameter, $\phi$ is a dimensionless parameter and $\omega$ is the angular frequency of ac voltage) and the polarization resistance $R_{\mathrm{p}}$ [42].

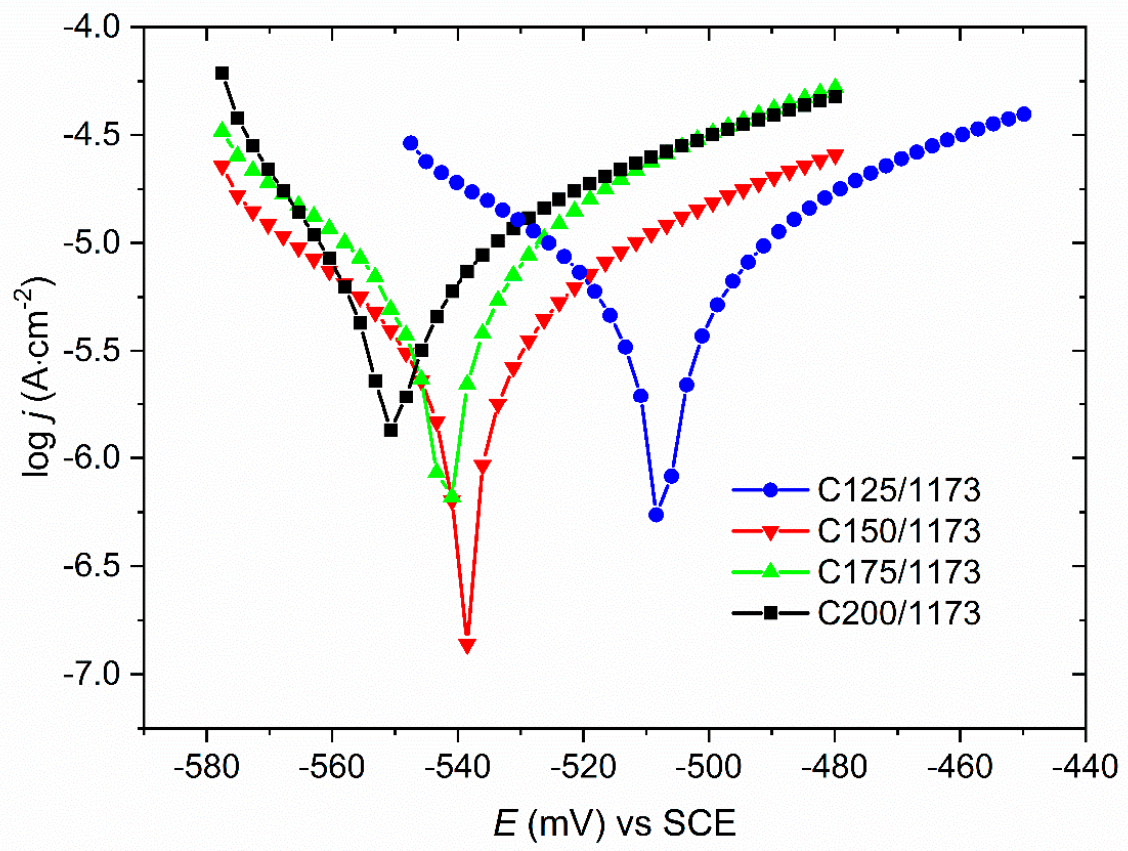

Figure 3. Potentiodynamic curves registered in $5 \mathrm{wt} . \% \mathrm{NaCl}$ solution for the $\mathrm{Ni}-\mathrm{W}$ coatings after heat treatment in the air, in dependence on deposition current density.

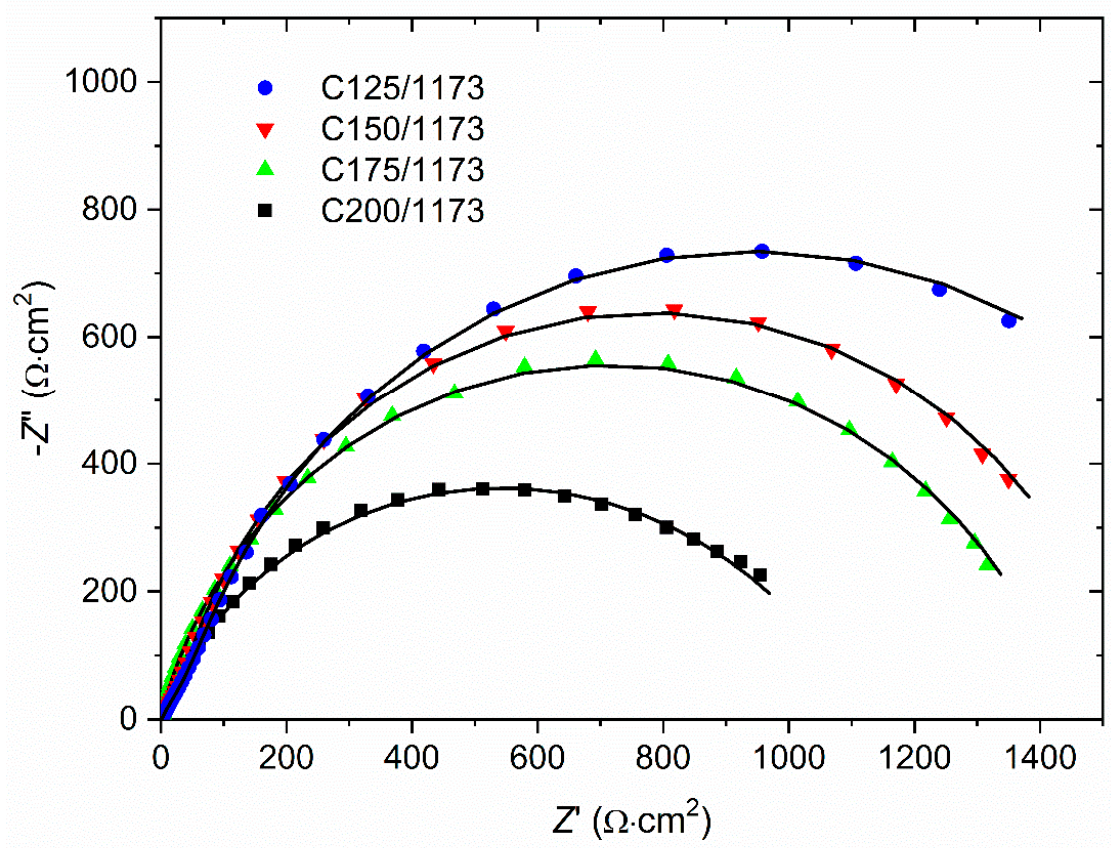

Figure 4. Nyquist plots registered in $5 \mathrm{wt} . \% \mathrm{NaCl}$ solution for the $\mathrm{Ni}-\mathrm{W}$ coatings after heat treatment in the air, in dependence on deposition current density; symbols-experimental points, solid lines-approximations using the one-CPE model. 
Table 2. Corrosion potential $E_{\text {corr }}$ and corrosion current density $j_{\text {corr }}$ determined for Ni-W coatings after heat treatment in the air, in dependence on deposition current density.

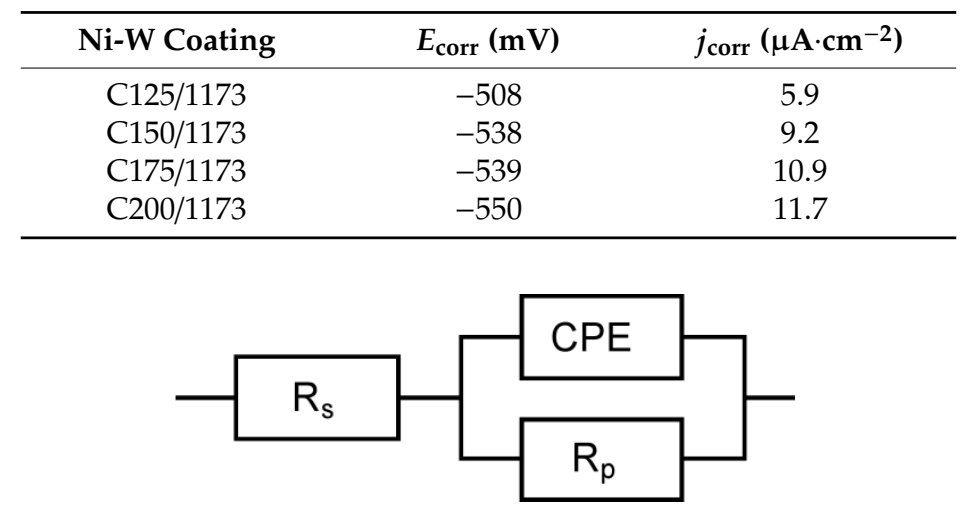

Figure 5. Equivalent circuit scheme, $R_{\mathrm{s}}$-solution resistance, $C P E$-constant phase element, $R_{\mathrm{p}}$-polarization resistance.

Approximations of the experimental impedances using the one-CPE model allowed to determine the following parameters: $R_{\mathrm{p}}, R_{\mathrm{s}}, T, \phi$ (Table 3). Note that lower values of polarization resistance $R_{\mathrm{p}}$ indicate that a material is more susceptible to corrosion.

Table 3. EIS parameters determined for Ni-W coatings after heat treatment in the air, in dependence on deposition current density.

\begin{tabular}{|c|c|c|c|c|c|}
\hline Ni-W Coating & $\begin{array}{c}R_{\mathrm{p}} \\
\left(\mathrm{k} \Omega \cdot \mathrm{cm}^{2}\right)\end{array}$ & $T$ & $\phi$ & $\begin{array}{c}R_{\mathrm{S}} \\
\left(\Omega \cdot \mathrm{cm}^{2}\right)\end{array}$ & $R_{\mathrm{f}}$ \\
\hline C125/1173 & 1.845 & 0.000146 & 0.87 & 1.19 & 2.00 \\
\hline C150/1173 & 1.535 & 0.000274 & 0.89 & 1.79 & 5.33 \\
\hline C175/1173 & 1.451 & 0.000328 & 0.89 & 1.51 & 6.39 \\
\hline C200/1173 & 1.122 & 0.000488 & 0.86 & 1.27 & 7.33 \\
\hline
\end{tabular}

$R_{\mathrm{p}}$ is the polarization resistance, $T$ is the capacitive parameter, $\phi$ is the parameter related to the rotation of the complex plane plot, $R_{\mathrm{s}}$ is the solution resistance, $R_{\mathrm{f}}$ is the factor of electrochemically active surface area.

The double-layer capacitance, $C_{\mathrm{dl}}$, was calculated according to [43]:

$$
T=C_{\mathrm{dl}} \phi\left(1 / R_{\mathrm{s}}+1 / R_{\mathrm{p}}\right)^{1-\phi}
$$

The ratio of capacitances $C_{\mathrm{dl}}$ determined for $\mathrm{Ni}-\mathrm{W}$ coating and ideally smooth nickel electrode $\left(20 \mu \mathrm{F} \cdot \mathrm{cm}^{-2}\right.$ [43]) gives factor of electrochemically active surface area, $R_{\mathrm{f}}$ (Table 3$)$. Larger values of this parameter indicate larger interfacial surface, and hence deterioration of material corrosion resistance. The smallest electrochemically active surface area and the highest polarization resistance obtained for C125/1173 sample clearly indicate that this coating exhibit the best anticorrosion properties compared with the other coatings.

Figure 6 shows CPD maps registered for the studied Ni-W coatings. Statistical analysis of the obtained maps allows determining parameters describing quantitatively the surface properties i.e. average $\left(C P D_{\mathrm{av}}\right)$ and root mean square $\left(C P D_{\mathrm{q}}\right)$ of contact potential difference [46-48]. It was stated that the $C 125 / 1173$ coating (Figure 6a, Table 4) is characterized by the highest value of $C P D_{\text {av }}$ which equals c.a. $-1060 \mathrm{mV}_{\mathrm{KP}}\left(\mathrm{mV}_{\mathrm{KP}}\right.$ is the voltage measured in relation to the Kelvin probe). Increasing of the deposition current density to $200 \mathrm{~mA} \cdot \mathrm{cm}^{-2}$ (Figure $6 \mathrm{~d}$, Table 4 ) causes that the $C P D_{\text {av }}$ decreases by about $140 \mathrm{mV}_{\mathrm{KP}}$. Deviation of the $C P D$ values from the mean (represented by $C P D_{\mathrm{q}}$ ) is the smallest for $\mathrm{C} 125 / 1173$ and equals c.a. $16 \mathrm{mV}_{\mathrm{KP}}$. It means that this coating shows the most homogeneous surface of all the coatings tested. It should be noted that in the case of C200/1173 coating, obtained at the highest current density, $C P D_{\mathrm{q}}$ increases more than two times in comparison with $C 125 / 1173$. Figure 7 
shows the tungsten content (at.\%) and corrosion current density $\left(j_{\text {corr }}\right)$ plotted versus the average contact potential difference $\left(C P D_{\mathrm{av}}\right)$. It has been found that the increase of tungsten content in the $\mathrm{Ni}-\mathrm{W}$ coating causes linear increase of $C P D_{\mathrm{av}}$. What is more, the corrosion rate (represented by $j_{\text {corr }}$ ) of $\mathrm{Ni}-\mathrm{W}$ coatings linearly decreases with increasing $C P D_{\mathrm{av}}$. Thus, $C P D_{\mathrm{av}}$ value allows estimating the corrosion rate of $\mathrm{Ni}-\mathrm{W}$ coatings after heat treatment in air.

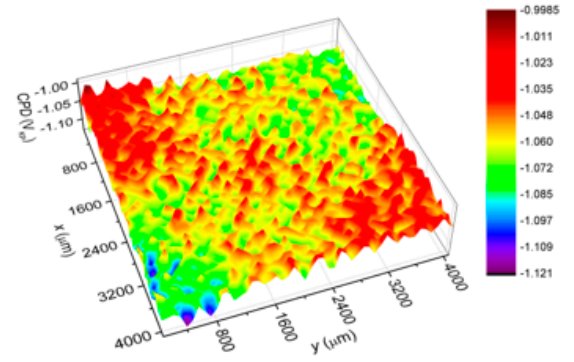

(a)

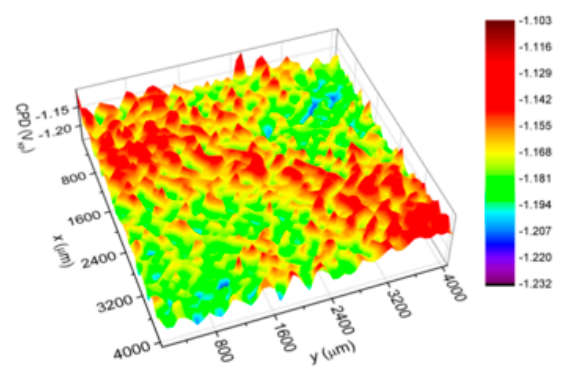

(c)

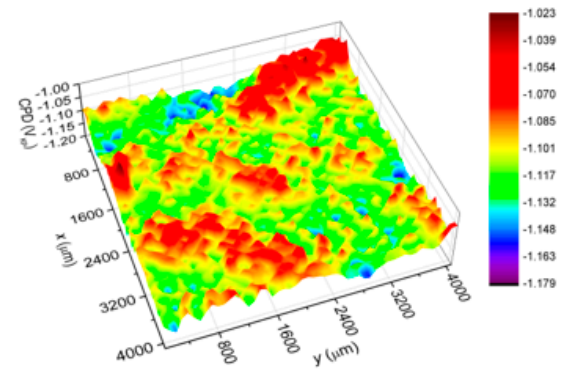

(b)

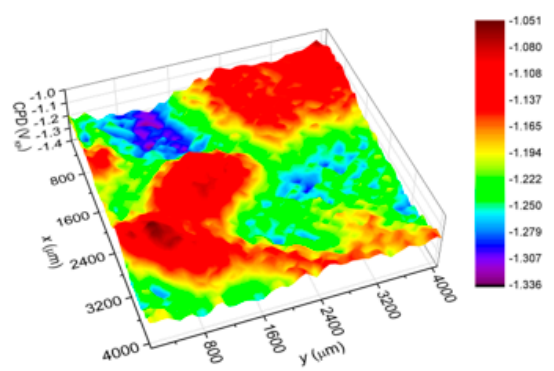

(d)

Figure 6. $C P D$ maps determined for the Ni-W coatings after heat treatment in the air: (a) $C 125 / 1173$, (b) $\mathrm{C} 150 / 1173$, (c) C175/1173 and (d) C200/1173.

Table 4. Statistical parameters obtained using CPD maps of the heat-treated Ni-W coatings.

\begin{tabular}{ccccc}
\hline Ni-W Coating & $\mathbf{C 1 2 5 / 1 1 7 3}$ & $\mathbf{C 1 5 0 / 1 1 7 3}$ & $\mathbf{C 1 7 5 / 1 1 7 3}$ & $\mathrm{C200/1173}$ \\
\hline $\begin{array}{c}C P D_{\mathrm{av}} \\
\left(\mathrm{m} \mathrm{V}_{\mathrm{KP}}\right)\end{array}$ & -1058 & -1104 & -1169 & -1194 \\
$\begin{array}{c}C P D_{\mathrm{q}} \\
\left(\mathrm{m} \mathrm{V}_{\mathrm{KP}}\right)\end{array}$ & 16 & 22 & 17 & 55
\end{tabular}

$C P D_{\mathrm{av}}$-average value, $C P D_{\mathrm{q}}$-root mean square, $\mathrm{mV}_{\mathrm{KP}}$ is the voltage measured in relation to the Kelvin probe.

Figure 8 shows surface topography maps of the heat-treated $\mathrm{Ni}-\mathrm{W}$ coatings obtained at deposition current density $125 \mathrm{~mA} \cdot \mathrm{cm}^{-2}$ (a) and $200 \mathrm{~mA} \cdot \mathrm{cm}^{-2}$ (b). Maps allow determining parameters describing quantitatively the surface roughness i.e. root mean square roughness $\left(S_{\mathrm{q}}\right)$, maximum peak height $\left(S_{\mathrm{p}}\right)$ and maximum pit depth $\left(S_{\mathrm{v}}\right)$. It was found that for the C125/1173 coating $S_{\mathrm{q}}=0.8 \mu \mathrm{m}, S_{\mathrm{p}}=2.9 \mu \mathrm{m}$, $S_{\mathrm{v}}=2.6 \mu \mathrm{m}$ and for C200/1173 coating $S_{\mathrm{q}}=9.8 \mu \mathrm{m}, S_{\mathrm{p}}=20.9 \mu \mathrm{m}, S_{\mathrm{v}}=21.1 \mu \mathrm{m}$. It can be concluded that both coatings are characterized by a uniform distribution of peaks and valleys heights around the mean. However, it should be noted that for C200/1173 coating $S_{\mathrm{p}}$ and $S_{\mathrm{v}}$ parameters are 7-8 times higher in comparison with $C 125 / 1173$. This fact can be explained by that as the deposition current density increases, the small globules visible on the C125/1173 surface (see Figure 1) change into larger 
ones. It was also stated that the deviation of peaks and valleys heights around the mean ( $S_{\mathrm{q}}$ parameter) for C200/1173 is higher. This is due to the fact that the $S_{\mathrm{q}}$ parameter is directly related to the heights of peaks and valleys on the material surface.

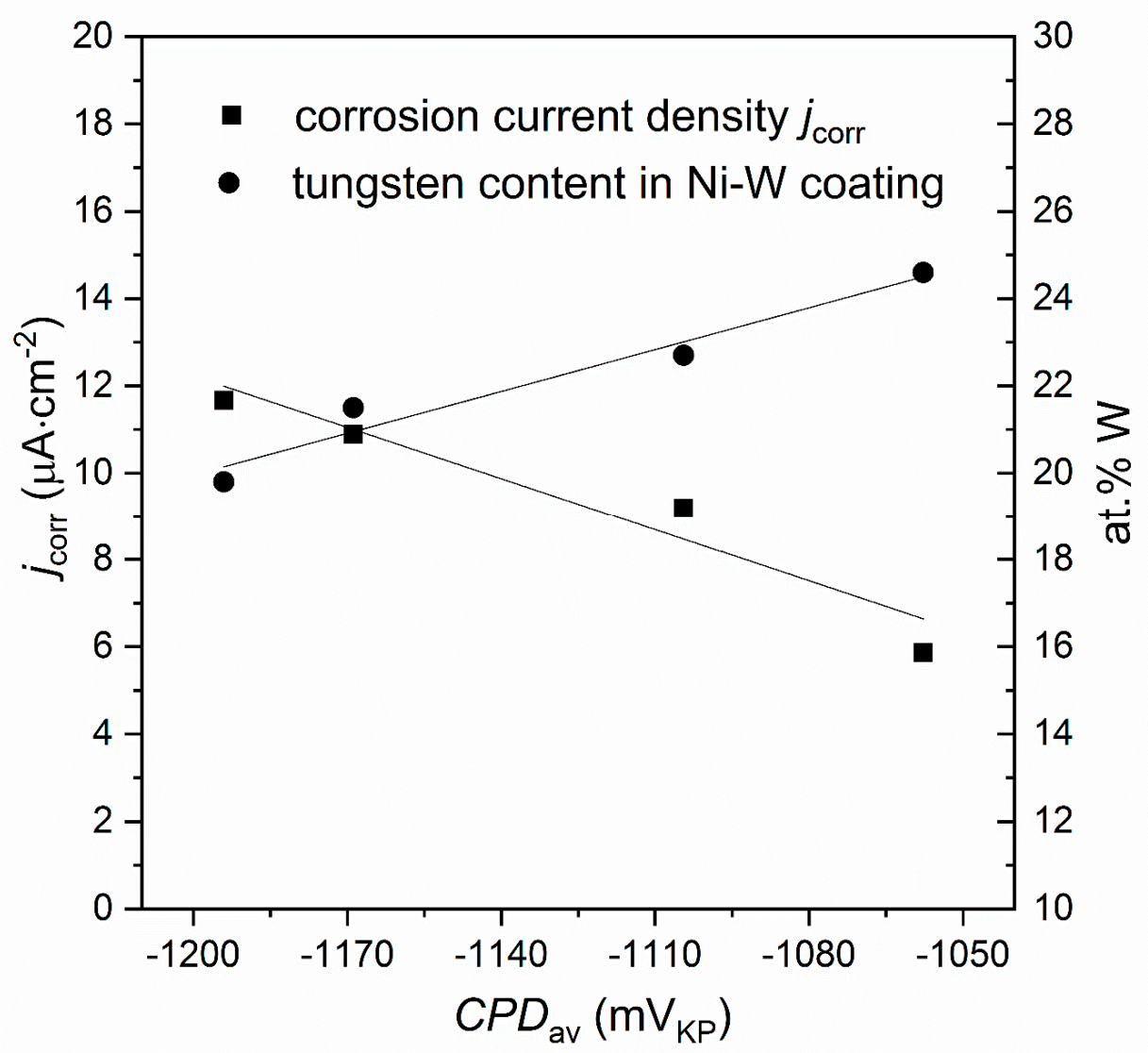

Figure 7. Tungsten content (at.\%) and corrosion current density $\left(j_{\text {corr }}\right)$ versus average contact potential difference $\left(C P D_{\text {av }}\right)$ determined for the $\mathrm{Ni}-\mathrm{W}$ coatings; $\mathrm{mV}_{\mathrm{KP}}$ is the voltage measured in relation to the Kelvin probe.

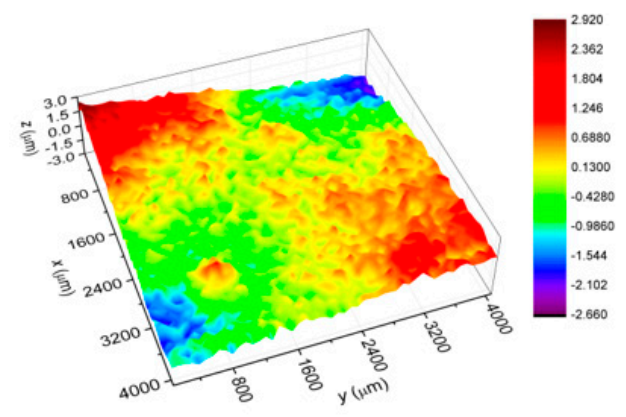

(a)

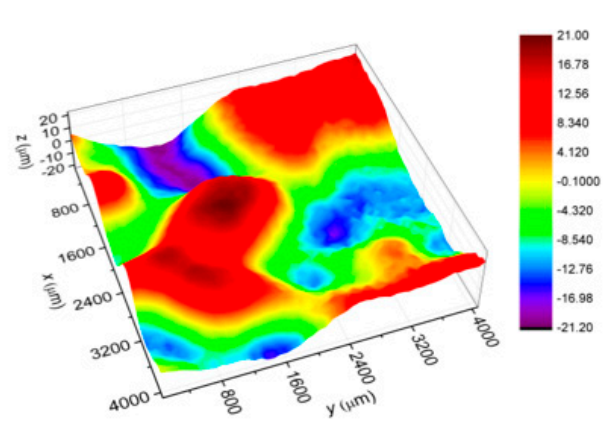

(b)

Figure 8. Topography maps determined for the heat-treated Ni-W coatings: (a) C125/1173 and (b) C200/1173.

\section{Conclusions}

It was found that $\mathrm{C} 125 / 1173$ coating is the most resistant to corrosion in $5 \mathrm{wt} . \% \mathrm{NaCl}$ solution of all the coatings tested. This is evidenced by the highest values of the corrosion potential, average contact 
potential difference and polarization resistance as well as the lowest value of the corrosion current density. The reason for this is the highest tungsten content in C125/1173 and the smallest surface area of this coating. Analysis of contact potential difference distribution shows also that the C125/1173 coating is characterized by the most homogeneous surface of all the coatings tested.

Author Contributions: Conceptualization, M.P. and J.K.; Methodology, M.P., J.K. and A.S.S.; Investigation, M.P. and J.K.; Resources, M.P. and J.K.; Formal Analysis, M.P., J.K. and A.S.S.; Writing-Original Draft Preparation, M.P., J.K. and A.S.S.; Data Curation, M.P., J.K., Z.W. and A.S.; writing-review and editing, Z.W., B.K. and A.S.; visualization, Z.W. and A.S.; All authors have read and agreed to the published version of the manuscript.

Funding: This research received no external funding.

Conflicts of Interest: The authors declare no conflict of interest.

\section{References}

1. Wang, Y.; Zhou, Q.; Li, K.; Zhong, Q.; Bui, Q.B. Preparation of Ni-W-SiO ${ }_{2}$ nanocomposite coating and evaluation of its hardness and corrosion resistance. Ceram. Int. 2015, 41, 79-84. [CrossRef]

2. Popczyk, M. The influence of molybdenum and silicon on activity of $\mathrm{Ni}+\mathrm{W}$ composite coatings in the hydrogen evolution reaction. Surf. Interface Anal. 2008, 40, 246-249. [CrossRef]

3. Allahyarzadeh, M.H.; Aliofkhazraei, M.; Sabour Rouhaghdam, A.R.; Torabinejad, V. Electrodeposition of $\mathrm{Ni}-\mathrm{W}-\mathrm{Al}_{2} \mathrm{O}_{3}$ nanocomposite coating with functionally graded microstructure. J. Alloys Compd. 2016, 666, 217-226. [CrossRef]

4. Popczyk, M.; Zacharz, M.; Osak, P.; Dercz, G.; Łosiewicz, B. Structure and corrosion resistance of nickel-molybdenum alloy coatings. Acta Phys. Pol. A 2016, 130, 1072-1074. [CrossRef]

5. Beltowska-Lehman, E.; Indyka, P.; Bigos, A.; Szczerba, M.; Kot, M. Ni-W/ZrO ${ }_{2}$ nanocomposites obtained by ultrasonic DC electrodeposition. Mater. Des. 2015, 80, 1-11. [CrossRef]

6. Hou, K.-H.; Sheu, H.-H.; Ger, M.-D. Preparation and wear resistance of electrodeposited Ni-W/diamond composite coatings. Appl. Surf. Sci. 2014, 308, 372-379. [CrossRef]

7. Hosseini, M.; Teymorinia, H.; Farzaneh, A.; Khameneh-asl, S. Evaluation of corrosion, mechanical and structural properties of new Ni-W-PCTFE nanocomposite coating. Surf. Coat. Technol. 2016, 298, 114-120. [CrossRef]

8. Popczyk, M. The hydrogen evolution reaction on electrolytic nickel - based coatings containing metallic molybdenum. Mater. Sci. Forum 2010, 636-637, 1036-1041. [CrossRef]

9. Beltowska-Lehman, E.; Indyka, P.; Bigos, A.; Kot, M.; Tarkowski, L. Electrodeposition of nanocrystalline Ni-W coatings strengthened by ultrafine alumina particles. Surf. Coat. Technol. 2012, 211, 62-66. [CrossRef]

10. Popczyk, M.; Kubisztal, J.; Budniok, A. Structure and electrochemical characterization of electrolytic $\mathrm{Ni}+\mathrm{Mo}+\mathrm{Si}$ composite coatings in an alkaline solution. Electrochim. Acta 2006, 51, 6140-6144. [CrossRef]

11. Wykpis, K.; Popczyk, M.; Budniok, A. Electrolytic deposition and corrosion resistance of Zn-Ni coatings obtained from sulphate-chloride bath. Bull. Mater. Sci. 2011, 34, 997-1001. [CrossRef]

12. Wykpis, K.; Popczyk, M.; Niedbała, J.; Budniok, A.; Eagiewka, E. Influence of the current density of deposition on the properties of Zn-Ni coatings. Mater. Sci. 2012, 47, 838-847. [CrossRef]

13. Wykpis, K.; Popczyk, M.; Niedbała, J.; Budniok, A.; Łagiewka, E.; Bierska-Piech, B. Influence of thermal treatment on the corrosion resistance of electrolytic Zn-Ni coatings. Mater. Sci-Poland 2012, 29, 177-183. [CrossRef]

14. Hashemi, M.; Mirdamadi, S.; Rezaie, H. Effect of SiC nanoparticles on microstructure and wear behavior of Cu-Ni-W nanocrystalline coating. Electrochim. Acta 2014, 138, 224-231. [CrossRef]

15. Popczyk, M.; Budniok, A.; Łagiewka, E. Structure and corrosion resistance of nickel coatings containing tungsten and silicon powders. Mater. Charact. 2007, 58, 371-375. [CrossRef]

16. Wykpis, K.; Niedbała, J.; Popczyk, M.; Budniok, A.; Łagiewka, E. The electrodeposition and properties of Zn-Ni+Ni composite coatings. Russ. J. Electrochem. 2012, 48, 1123-1129. [CrossRef]

17. Wykpis, K.; Popczyk, M.; Niedbała, J.; Bierska-Piech, B.; Budniok, A.; Łagiewka, E. Influence of thermal treatment on the corrosion resistance of electrolytic $\mathrm{Zn}-\mathrm{Ni}+\mathrm{Ni}$ composite coatings. Adv. Compos. Mater. 2015, 24, 431-438. [CrossRef] 
18. Popczyk, M.; Serek, A.; Budniok, A. Production and properties of composite layers based on an Ni-P amorphous matrix. Nanotechnology 2003, 14, 341-346. [CrossRef]

19. Zemanová, M.; Druga, J.; Szúnyogh, J.; Dobročka, E. Ni-W alloys for hydrogen evolution. Mater. Sci. Forum 2016, 844, 167-171. [CrossRef]

20. Yang, F.-Z.; Guo, Y.F.; Huang, L.; Xu, S.K.; Zhou, S.M. Electrodeposition, structure and corrosion resistance of nanocrystalline Ni-W alloy. Chinese J. Chem. 2004, 22, 228-231.

21. Obradović, M.; Stevanović, J.; Despić, A.; Stevanović, R.; Stoch, J. Characterization and corrosion properties of electrodeposited Ni-W alloys. J. Serb. Chem. Soc. 2001, 66, 899-912. [CrossRef]

22. Allahyarzadeh, M.H.; Aliofkhazraei, M.; Rezvanian, A.R.; Torabinejad, V.; Sabour Rouhaghdam, A.R. Ni-W electrodeposited coatings: Characterization, properties and applications. Surf. Coat. Tech. 2016, 307, 978-1010. [CrossRef]

23. Quiroga Argañaraz, M.P.; Ribotta, S.B.; Folquer, M.E.; Gassa, L.M.; Benítez, G.; Vela, M.E.; Salvarezza, R.C. $\mathrm{Ni}-\mathrm{W}$ coatings electrodeposited on carbon steel: Chemical composition, mechanical properties and corrosion resistance. Electrochim. Acta 2011, 56, 5898-5903. [CrossRef]

24. Alimadadi, H.; Ahmadi, M.; Aliofkhazraei, M.; Younesi, S.R. Corrosion properties of electrodeposited nanocrystalline and amorphous patterned Ni-W alloy. Mater. Des. 2009, 30, 1356-1361. [CrossRef]

25. Mroz, K.P.; Bigos, A.; Kucharski, S.; Dolinski, K.; Bełtowska-Lehman, E. Ni-W electrodeposited coatings on low carbon steel substrate: Fatigue observations. J. Mater. Eng. Perform. 2014, 23, 3459-3466. [CrossRef]

26. Indyka, P.; Bełtowska-Lehman, E.; Tarkowski, L.; Bigos, A.; García-Lecina, E. Structure characterization of nanocrystalline Ni-W alloys obtained by electrodeposition. J. Alloy Compd. 2014, 590, 75-79. [CrossRef]

27. Kirihara, S.; Umeda, Y.; Tashiro, K.; Honma, H.; Takai, O. Development of Ni-W alloy plating as a substitution of hard chromium plating. Trans. Mater. Res. Soc. Jpn. 2016, 41, 35-39. [CrossRef]

28. Jones, A.R.; Hamann, J.; Lund, A.C.; Schuh, C.A. Nanocrystalline Ni-W alloys coating for engineering applications. Plat. Surf. Finish. 2010, 97, 52-60.

29. Wasekar, N.P.; Sundararajan, G. Sliding wear behavior of electrodeposited Ni-W alloy and hard chrome coatings. Wear 2015, 342-343, 340-348. [CrossRef]

30. Lee, H.B. Synergy between corrosion and wear of electrodeposited Ni-W coating. Tribol. Lett. 2013, 50, 407-419. [CrossRef]

31. Chianpairot, A.; Lothongkum, G.; Schuh, C.A.; Boonyongmaneerat, Y. Corrosion of nanocrystalline Ni-W alloys in alkaline and acidic 3.5 wt.\% NaCl solutions. Corros. Sci. 2011, 53, 1066-1071. [CrossRef]

32. Chen, H.; Ren, X.R.; Zhang, X.H.; Li, J.H. Wear and corrosion properties of crystalline Ni-W alloy coatings prepared by electrodeposition. Mater. Sci. Forum 2016, 849, 671-676. [CrossRef]

33. de Lima-Neto, P.; Correia, A.N.; Santana, R.A.C.; Colares, R.P.; Barros, E.B.; Casciano, P.N.S.; Vaz, G.L. Morphological, structural, microhardness and electrochemical characterizations of electrodeposited $\mathrm{Cr}$ and Ni-W coatings. Electrochim. Acta 2010, 55, 2078-2086. [CrossRef]

34. Kaninski, M.P.M.; Saponjic, D.P.; Perovic, I.M.; Maksic, A.D.; Nikolic, V.M. Electrochemical characterization of the Ni-W catalyst formed in situ during alkaline electrolytic hydrogen production-Part II. Appl. Catal. A Gen. 2011, 405, 29-35. [CrossRef]

35. Tasić, G.S.; Lačnjevac, U.; Tasić, M.M.; Kaninski, M.M.; Nikolić, V.M.; Žugić, D.L.; Jović, V.D. Influence of electrodeposition parameters of $\mathrm{Ni}-\mathrm{W}$ on $\mathrm{Ni}$ cathode for alkaline water electrolyser. Int. J. Hydrog. Energy 2013, 38, 4291-4297.

36. Chen, S.H.; Lai, J.H.; Wu, M.Y.; Lee, H.B.; Lee, C.Y. A study on the corrosion and wear behavior of electrodeposited Ni-W coatings. J. Chin. Corros. Eng. 2012, 26, 1-8.

37. Sriraman, K.; Raman, S.G.S.; Seshadri, S. Corrosion behaviour of electrodeposited nanocrystalline Ni-W and Ni-Fe-W alloys. Mater. Sci. Eng. A 2007, 460, 39-45. [CrossRef]

38. Sunwang, N.; Wangyao, P.; Boonyongmaneerat, Y. The effects of heat treatments on hardness and wear resistance in Ni- W alloy coatings. Surf. Coat. Technol. 2011, 206, 1096-1101. [CrossRef]

39. Ko, Y.-K.; Chang, G.-H.; Lee, J.-H. Nickel tungsten alloy electroplating for the high wear resistant materials applications. Solid State Phenom. 2007, 124-126, 1589-1592.

40. Popczyk, M.; Łosiewicz, B. Influence of surface development of Ni/W coatings on the kinetics of the electrolytic hydrogen evolution. Solid State Phenom. 2015, 228, 293-298. [CrossRef] 
41. Popczyk, M.; Łosiewicz, B.; Łagiewka, E.; Budniok, A. Influence of thermal treatment on the electrochemical properties of Ni+Mo composite coatings in an alkaline solution. Solid State Phenom. 2015, 228, 231-236. [CrossRef]

42. Karimi-Shervedani, R.; Lasia, A. Studies of the hydrogen evolution reaction on Ni-P electrodes. J. Electrochem. Soc. 1997, 144, 511-519. [CrossRef]

43. Karimi-Shervedani, R.; Lasia, A. Evaluation of the surface roughness of microporous Ni-Zn-P electrodes by in situ methods. J. Appl. Electrochem. 1999, 29, 979-986. [CrossRef]

44. Hou, K.-H.; Chang, Y.-F.; Chang, S.-M.; Chang, C.-H. The heat treatment effect on the structure and mechanical properties of electrodeposited nano grain size Ni-W alloy coatings. Thin Solid Films 2010, 518, 7535-7540. [CrossRef]

45. Lasia, A. Nature of the two semi-circles observed on the complex plane plots on porous electrodes in the presence of a concentration gradient. J. Electroanal. Chem. 2001, 500, 30-35. [CrossRef]

46. Kubisztal, J.; Kubisztal, M.; Haneczok, G. Quantitative characterization of material surface-application to Ni + Mo electrolytic composite coatings. Mater. Charact. 2016, 122, 45-53. [CrossRef]

47. Kubisztal, J.; Kubisztal, M.; Stach, S.; Haneczok, G. Corrosion resistance of anodic coatings studied by scanning microscopy and electrochemical methods. Surf. Coat. Tech. 2018, 350, 419-427. [CrossRef]

48. Bak, A.; Losiewicz, B.; Kozik, V.; Kubisztal, J.; Dybal, P.; Swietlicka, A.; Barbusinski, K.; Kus, S.; Howaniec, N.; Jampilek, J. Real-time corrosion monitoring of AISI 1010 carbon steel with metal surface mapping in sulfolane. Materials 2019, 12, 3276. [CrossRef]

(C) 2020 by the authors. Licensee MDPI, Basel, Switzerland. This article is an open access article distributed under the terms and conditions of the Creative Commons Attribution (CC BY) license (http://creativecommons.org/licenses/by/4.0/). 